\title{
THE EARLY DEVELOPMENT OF TETRAPOD HERBIVORY
}

BEERBOWER*, Richard, Dept. of Geol. Sciences, State Univ. of N.Y., Binghamton, NY 13902-6000, U.S.A.; OLSON, Everett C., Dept. of Biology, 405 Hilgard Ave., Univ. of California, Los Angles, CA 90024, U.S.A.; HOTTON, Nicholas, III, Dept. of Paleobiology, Rm 102E NHB, Smithsonian, Washington, DC 20560, U.S.A.

Herbivorous tetrapods make their first appearance in Upper Carboniferous fossil assemblages but only become abundant and diverse in Upper Permian ones. During the Late Carboniferous-Early Permian interval, herbivory appeared independently at least five times: in diadectids, bolosaurids, captorhinids, edaphosaurids and caseids. These animals ranged from small forms with aptitudes for collection and processing of low-fiber plant tissues (as well as terrestrial invertebrates) to giants particularly apt for utilization of high-fiber tissues. Our report focuses on the latter group since the development of high-fiber herbivory has had a critical impact on evolution of terrestrial plants and animals as well as on the organization of terrestrial ecosystems.

The low abundance and diversity of early, high-fiber herbivores reflect on one hand, sampling biases toward habitats suboptimal for herbivory, and on the other, the limited ecological capabilities of the animals themselves. Most of the Permo-Carboniferous assemblages derive from wet-land swamp and forest ecosystems where plant tissues would have been relatively rare and/or inaccessible and predation relatively intense. The likely herbivores appear apt for life in wet-land ecosystems; there they probably utilized localized patchs of productive shrub and herb along rivers and around lakes as refuges from disturbance (desiccation, temperature extremes and predation) as well as sources of food. Their low metabolic levels and growth rates minimized nutritional requirements but along with large size provided adequately for adult maintenance and for reproduction. High adult survivorship and production of a large number of eggs through a long adult lifespan would have offset high egg and juvenile mortality.

Only a few Late Carboniferous and Early Permian assemblages sample drier woodland and shrub habitats where conditions would have been more favorable for high-fiber herbivory, but by Late Permian such assemblages occur in much greater numbers and diversity. The high-fiber herbivores in these dry-land ecosystems had ecological aptitudes comparable to wet-land forms but were relatively more abundant and diverse, reflecting both a greater abundance and extent of shrubby vegetation and a lower incidence of predation. 